\title{
EVALUASI SARANA PENYEHATAN LINGKUNGAN RUMAH SUSUN Studi Kasus di Kawasan Rumah Susun Pejompongan Jakarta Pusat
}

\author{
Dedi Ismail, Prihantono, Santoso Sri Handoyo
}

\begin{abstract}
This research operationally was purposeful to evaluate means of sanitation of the high-rise flat environment that is: the clean water, air and ventilation, information, the dirty disposal and the rain water as well as the waste of the water.

The research was carried out in the Region of the Flat High-rise Flat of Benhil I Pejompongan Jakarta of the Centre through the descriptive research kind technically the survey and made use of the instrument of the research took the form of the numbering questionnaire of 40 items of the matter.

Results of the research that were received were based on results and observation of the survey that were carried out showed that means of environmental sanitation in the high-rise flat region of Pejompongan Jakarta of the Centre that covered: the clean water, air and ventilation, information, the dirty disposal and the rain water as well as the waste of the water filled the condition for the health.
\end{abstract}

\section{PENDAHULUAN}

Pembangunan rumah sebagai salah satu kebutuhan utama bagi warga terutama di kota-kota besar telah menjadi masalah pokok yang sangat penting untuk saat ini maupun dimasa mendatang. Seiring dengan kebutuhan tersebut, pihak pemerintah kota berusaha semaksimal mungkin untuk dapat memenuhinya dengan menyediakan daerah pemukiman yang baru. Namun untuk mewujudkan hal tersebut, kini timbul berbagai masalah yang harus dihadapi.

Sulitnya mencari lahan yang tepat sesuai dengan peruntukan sebagai lahan pemukiman menjadi masalah tersendiri bagi kota-kota besar seperti kota Jakarta, lalu kurangnya kemampuan masyarakat terutama mereka yang berpenghasilan rendah untuk membiayai pembangunan perumahan maupun lingkungan yang layak juga harus dipikirkan oleh pihak pemerintah kota. Salah satu usaha untuk mengatasi masalah tersebut adalah diadakan program penyediaan 
rumah susun. Program ini dimaksudkan untuk lebih meningkatkan efisiensi dan efektivitas penggunaan tanah di dalam kota, serta dikaitkan pula dengan usaha peremajaan bagian-bagian kota yang mempunyai kondisi sudah tidak lagi memenuhi syarat-syarat lingkungan perumahan dan pemukiman yang sehat.

Dipandang dari aspek kesehatan masyarakat pada umumnya serta kesehatan lingkungan pada khususnya, sesungguhnya kondisi rumah susun harus memenuhi syarat-syarat kesehatan. Beberapa hal pokok yang terutama diperlukan untuk mendukung terciptanya kondisi perumahan dan lingkungan yang layak serta memenuhi syarat rumah sehat yaitu telah terpenuhinya : (Budihardjo, 1984)

1. Penyediaan sarana dan pengawasan kualitas air bersih.

2. Pembuangan sampah dan air limbah.

3. Penyediaan sarana pembuangan kotoran.

4. Penyediaan fasilitas dan pelayanan umum.

Melihat pentingnya aspek kesehatan lingkungan pada rumah susun terutama pada penyediaan sarana penyehatan lingkungannya dipandang perlu adanya suatu evaluasi tentang sarana penyehatan lingkungan di kawasan rumah susun yang meliputi air bersih, sampah, penerangan, udara dan ventilasi, serta pembuangan air kotor dan air hujan.

Berdasarkan hal tersebut di atas, penyusun tertarik untuk mengadakan evaluasi tentang sarana penyehatan lingkungan pada rumah susun sederhana di kawasan Pejompongan Jakarta Pusat.

\section{METODA}

Penelitian ini secara operasional bertujuan untuk mengadakan evaluasi tentang sarana penyehatan lingkungan rumah susun yaitu : air bersih, udara dan ventilasi, penerangan, pembuangan air kotor dan air hujan serta sampah.

Penelitian ini dilaksanakan dikawasan rumah susun sederhana di Pejompongan Jakarta Pusat pada bulan Maret sampai dengan bulan April 2004 
Metode penelitian yang digunakan dalam penelitian ini merupakan penelitian deskriptif dengan teknik survei yaitu penelitian untuk mengumpulkan informasi tentang status atau gejala yang berhubungan dengan sarana penyehatan lingkungan pada rumah susun.

Mengingat data yang digunakan dalam penelitian ini bersifat survei, maka teknik pengumpulan data hanya dengan melihat sarana penyehatan lingkungan rumah susun. Dengan membuat urutan pertanyaan yang berkaitan langsung dengan sarana penyehatan lingkungan berdasarkan syarat-syarat penyehatan lingkungan rumah susun yang telah ditentukan, sedangkan untuk mendapatkan keterangan-keterangan lain yang dianggap perlu untuk memperlancar pengolahan data, penelitian dilakukan melalui diskusi wawancara dengan penghuni rumah susun di kawasan Pejompongan Jakarta Pusat.

\section{HASIL DAN PEMBAHSAN}

\section{A. Deskripsi Data}

Berdasarkan judul dan tujuan penelitian yaitu untuk memperoleh jawaban atas pembuktian yang dapat diandalkan mengenai penilaian terhadap sarana penyehatan ligkungan melalui pengukuran dimensi-dimensi yang ada, yaitu: air bersih, udara dan ventilasi, penerangan, pembuangan air kotor dan air hujan serta sampah.

Adapun uraian data ini dapat dilihat dari hasil survei terhadap 40 unit rumah susun dan hasil dari wawancara dengan pihak pengelola dan juga para penghuni.

1) Air bersih

a) Air bersih yang digunakan untuk keperluan sehari-hari bersumber dari PALIJA (PDAM).

b) Penggunaan air bersih per bulan $015.000 \mathrm{m3} / 296$ unit, per harinya $\square 500 \mathrm{m3} / 296$ unit atau 1,6m3 /unit/hari sama dengan 1600 liter/unit rumah/hari.

c) Tiap unit tersedia 1 meteran air.

d) Pendistribusian menggunakan pipa PVC dengan ukuran $1 / 4$ inci.

2) Udara dan Ventilasi

a) Luas lantai $3 \times 6 \mathrm{~m}$, luas ventilasi $0,2 \times 0,6 \mathrm{~m}$ sebanyak 4 buah.

b) Serta jendela dengan ukuran $1 \times 0,6 \mathrm{~m}$ sebanyak 2 buah. 
c) Udara di lingkungan rumah susun tidak tercemar oleh asap kendaraan bermotor.

3) Penerangan

a) Aliran udara banyak terhalang antara lain oleh jemuran para penghuni yang digantung di depan jendela dan ventilasi udara.

b) Hanya sebagian sinar matahari yang masuk ke dalam ruangan.

c) Luas lantai $3 \times 6 \mathrm{~m}$, jendela dengan ukuran $1 \times 0,6 \mathrm{~m}$ sebanyak 3 buah.

d) Untuk menerangi ruangan sebesar $3 \times 6 \mathrm{~m}$, di tiap unit rumah susun digunakan lampu sebesar 30 Watt.

4) Saluran Pembuangan air kotor dan air hujan

a) Pipa penyalur dengan pipa PVC ukuran 4 inchi disalurkan ke tangki septik.

b) Untuk melayani 3 blok rumah susun, disediakan 5 buah tangki septik dengan ukuran sama besar yaitu $2 \times 2 \times 5 \mathrm{~m}$.

c) Dilakukan pengurasan jika sudah penuh saja, kira-kira setiap 3 tahun sekali.

d) Tidak menggunakan Saluran berbentuk $1 / 2$ lingkaran.

e) Saluran terbuka dengan bentuk bulat telur dengan ukuran $20 / 30 \mathrm{~cm}$.

f) Saluran ini terbuat dari beton.

5) Sampah

a) Untuk sampah rumah tangga, berukuran $0,4 \times 0,4 \times 0,8 \mathrm{~m}$.

b) Bak penampungan sampah lingkungan ukuran $2 \times 3 \times 2 \mathrm{~m}$.

c) Tempat sampah rumah tangga terbuat dari plastik dan lingkungan terbuat dari beton.

d) Sampah rumah tangga diangkut tiap hari dan sampah lingkungan ini dilakukan tiap seminggu sekali.

\section{B. Pengolahan Data}

Dari hasil survei dan pengamatan yang dilakukan terhadap sarana penyehatan lingkungan yang terdapat di kawasan rumah susun Pejompongan, didapat data yang akan diolah dengan 
membandingkan dan menganalisa dengan standar yang berlaku dalam bentuk tabel sebagai berikut:

1) Air bersih

Tabel 3. Perbandingan keadaan air bersih dengan standar.

\begin{tabular}{|c|c|}
\hline Standar & Keadaan sebenarnya \\
\hline $\begin{array}{l}\text { a. Sumber air bersih yang memenuhi } \\
\text { persyaratan air minum. } \\
\text { b. Kebutuhan sambungan rumah minimum } \\
150 \text { liter/orang/hari. } \\
\text { c. Harus tersedia meter air dengan ukuran } \\
12,5 \mathrm{~mm} \text {. } \\
\text { d. Untuk pendistribusian dipakai pipa PVC. }\end{array}$ & $\begin{array}{l}\text { a. Air bersih digunakan bersumber dari } \\
\text { PALIJA (PDAM). } \\
\text { b. Penggunaan air } 1,6 \mathrm{~m}^{3} \text { atau } \\
\text { 1600liter/unit rumah/hari. } \\
\text { c. Tiap unit tersedia } 1 \text { meteran air. } \\
\text { d. Pendistribusian menggunakan pipa } \\
\text { PVC dengan ukuran } 1 / 4 \text { inci. }\end{array}$ \\
\hline
\end{tabular}

Air bersih yang dipergunakan telah memenuhi syarat kesehatan dan juga telah memenuhi kebutuhan perhari dari para penghuninya.

Untuk pendistribusiannya juga sudah menggunakan pipa yang sesuai dengan peraturan yang berlaku, dan juga di tiap-tiap unit rumah telah dilengkapi dengan meteran air.

2). Udara dan ventilasi

Tabel 4. Perbandingan keadaan udara dan ventilasi dengan standar.

\begin{tabular}{|l|l|}
\hline \multicolumn{1}{|c|}{ Standar } & \multicolumn{1}{|c|}{ Keadaan sebenarnya } \\
\hline $\begin{array}{l}\text { Luas lubang ventilasi minimum 5\% dari luas } \\
\text { lantai ruangan. }\end{array}$ & $\begin{array}{l}\text { Luas lantai } 3 \times 6 \mathrm{~m} \text {, luas ventilasi 0,2 } \\
0,6 \mathrm{~m} \text { sebanyak } 4 \text { buah. Serta jendela } \\
\text { dengan ukuran } 1 \times 0,6 \mathrm{~m} \text { sebanyak } 2 \\
\text { buah. }\end{array}$ \\
\hline $\begin{array}{l}\text { Udara yang masuk harus bersih, tidak } \\
\text { dicemari oleh asap dari sampah atau }\end{array}$ & $\begin{array}{l}\text { Udara di lingkungan rumah susun tidak } \\
\text { tercemar oleh asap kendaraan bermotor }\end{array}$ \\
\hline
\end{tabular}




\begin{tabular}{|l|l|}
\hline \multicolumn{1}{|c|}{ Standar } & \multicolumn{1}{|c|}{ Keadaan sebenarnya } \\
\hline knalpot kendaraan. & \\
\hline $\begin{array}{l}\text { Aliran udara jangan sampai terhadang oleh } \\
\text { barang-barang besar, misalnya lemari, } \\
\text { dinding sekat dan lain-lain. }\end{array}$ & $\begin{array}{l}\text { Aliran udara banyak terhalang antara lain } \\
\text { oleh jemuran para penghuni yang } \\
\text { digantung di depan jendela dan ventilasi } \\
\text { udara. }\end{array}$ \\
\hline
\end{tabular}

Ukuran lubang ventilasi yang digunakan di tiap-tiap unit rumah telah memenuhi ukuran yang berlaku dan juga udara yang ada disekitar lingkungan rumah susun telah memenuhi syarat karena tidak tercemar dari asap kendaraan ataupun yang lainnya.

Hanya ada kekurangan dari pertukaran udara yang terjadi di dalam ruangan, disebabkan karena para penghuni sering meletakan jemuran di depan ventilasi udara. Inilah yang membuat aliran udara menjadi terhalang.

3) Penerangan

Tabel 5. Perbandingan keadaan penerangan dalam ruangan dengan standar.

\begin{tabular}{|c|c|}
\hline Standar & Keadaan sebenarnya \\
\hline $\begin{array}{l}\text { a. Pada siang hari, terdapat cukup banyak } \\
\text { cahaya yang masuk kedalam ruangan. }\end{array}$ & $\begin{array}{l}\text { a. Hanya sebagian sinar matahari yang } \\
\text { masuk ke dalam ruangan. }\end{array}$ \\
\hline $\begin{array}{l}\text { b. Luas jedela paling sedikit mempunyai } \\
\text { luas } 10-20 \% \text { dari luas lantai. }\end{array}$ & $\begin{array}{l}\text { b. Luas lantai } 3 \times 6 \mathrm{~m} \text {, jendela dengan } \\
\text { ukuran } 1 \times 0,6 \mathrm{~m} \text { sebanyak } 3 \text { buah. }\end{array}$ \\
\hline $\begin{array}{l}\text { c. Penerangan buatan untuk rumah per } \mathrm{m}^{2} \\
\text { adalah } 10-20 \text { Watt } / \mathrm{m}^{2} \text { (standar baku } \\
\text { belum didapatkan) }\end{array}$ & $\begin{array}{l}\text { c. Untuk menerangi ruangan sebesar } 3 \mathrm{x} \\
6 \mathrm{~m} \text {, di tiap unit rumah susun } \\
\text { digunakan lampu sebesar } 30 \text { Watt }\end{array}$ \\
\hline
\end{tabular}

Penerangan alami yang didapatkan dari sinar matahari, tidak semua unit mendapatkan sinar yang cukup. Dikarenakan tata letak bangunan yang tidak mengarah ke arah datang sinar tersebut. 
Untuk luas lubang jendela yang digunakan untuk mendapatkan sinar masuk sudah memenuhi kebutuhan dan juga penerangan buatan yang didapatkan dari lampu juga sudah baik dan memenuhi syarat.

4) Pembuangan air kotor dan air hujan

Tabel 6. Perbandingan keadaan pembuangan air kotor dan air hujan dengan standar.

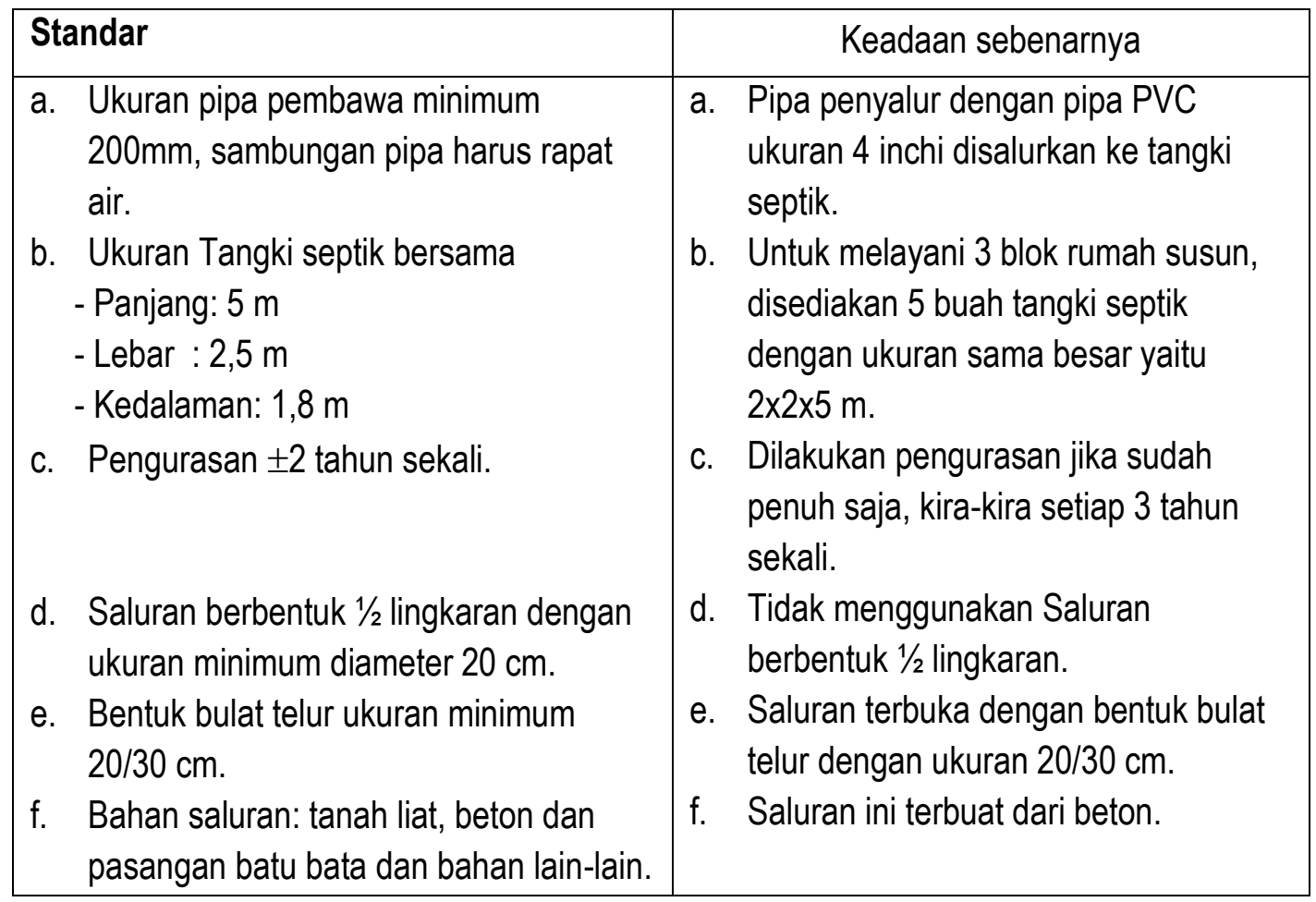

Penyaluran pembuangan air kotor dari tiap-tiap unit rumah susun dialirkan ke tangki septik. Menggunakan pipa penyalur yng telah memenuhi syarat dan ukuran tangki septiknyapun telah sesuai.

Untuk pembuangan air hujan, telah menggunakan ukuran saluran dan terbuat dari bahan yang memenuhi persyaratan. 
5) Sampah

Tabel 7. Perbandingan keadaan sampah dengan standar.

\begin{tabular}{|c|c|}
\hline Standar & Keadaan sebenarnya \\
\hline $\begin{array}{l}\text { a. Kapasitas minimum tempat sampah } \\
\text { rumah tangga } 0,02 \mathrm{~m}^{3} \text {. } \\
\text { b. Kapasitas tempat sampah lingkungan } \\
\text { minimum bervolume } 2 \mathrm{~m}^{3} \text {. } \\
\text { c. Tempat sampah dibuat dari bahan rapat } \\
\text { air. } \\
\text { d. Frekwensi Pengangkutan dari tiap-tiap } \\
\text { rumah atau pengumpulan sampah } \\
\text { harus maksimum } 2 \text { hari sekali. }\end{array}$ & $\begin{array}{l}\text { a. Untuk sampah rumah tangga, } \\
\text { berukuran 0,4 x 0,4 × 0,8 m. } \\
\text { b. Bak penampungan sampah } \\
\text { lingkungan ukuran } 2 \times 3 \times 2 \mathrm{~m} \text {. } \\
\text { c. Tempat sampah terbuat dari plastik } \\
\text { dan dari beton. } \\
\text { d. Sampah rumah tangga diangkut tiap } \\
\text { hari dan sampah lingkungan ini } \\
\text { dilakukan tiap seminggu sekali. }\end{array}$ \\
\hline
\end{tabular}

Kapasitas penampungan sampah yang tersedia sudah sesuai dengan syarat yang berlaku dan terbuat dari bahan yang telah sesuai. Dari frekwensi pengangkutannya juga telah memenuhi aturan yang berlaku.

\section{Hasil Penelitian}

Dari hasil analisa pengolahan data yang dilakukan terhadap sarana penyehatan lingkungan tersebut di atas, maka hasil penelitian yang dapat diuraikan adalah sebagai berikut.

Tabel 8. Hasil Penelitian terhadap sarana penyehatan lingkungan di rumah susun.

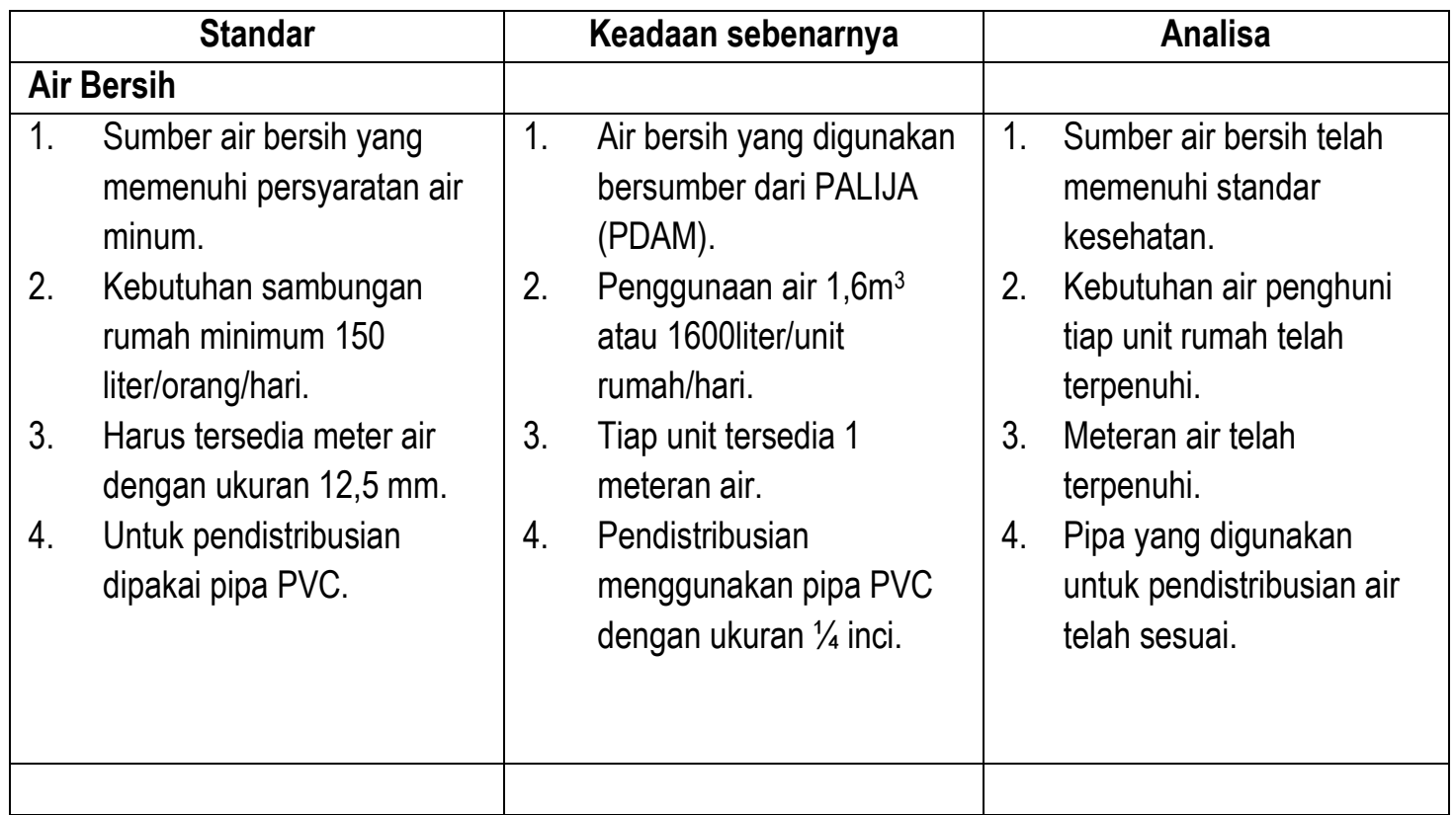




\begin{tabular}{|c|c|c|c|}
\hline Standar & & Keadaan sebenarnya & Analisa \\
\hline \multicolumn{4}{|l|}{ Udara dan ventilasi } \\
\hline $\begin{array}{l}\text { 1. Luas lubang ventilasi } \\
\text { minimum } 5 \% \text { dari luas } \\
\text { lantai ruangan. }\end{array}$ & 1. & $\begin{array}{l}\text { Luas lantai } 3 \times 6 \mathrm{~m} \text {, luas } \\
\text { ventilasi } 0,2 \times 0,6 \mathrm{~m} \\
\text { sebanyak } 4 \text { buah. Serta } \\
\text { jendela dengan ukuran } 1 \times \\
0,6 \mathrm{~m} \text { sebanyak } 2 \text { buah. }\end{array}$ & $\begin{array}{l}\text { 1. Luas lubang ventilasi telah } \\
\text { mencukupi } 5 \% \text { dari luas } \\
\text { ruangan. }\end{array}$ \\
\hline $\begin{array}{l}\text { 2. Udara yang masuk harus } \\
\text { bersih, tidak dicemari oleh } \\
\text { asap dari sampah atau } \\
\text { knalpot kendaraan. }\end{array}$ & 2. & $\begin{array}{l}\text { Udara di lingkungan } \\
\text { rumah susun tidak } \\
\text { tercemar oleh asap } \\
\text { kendaraan bermotor. }\end{array}$ & $\begin{array}{l}\text { 2. Udara di lingkungan } \\
\text { memenuhi syarat untuk } \\
\text { dihirup. }\end{array}$ \\
\hline $\begin{array}{l}\text { 3. Aliran udara jangan sampai } \\
\text { terhadang oleh barang- } \\
\text { barang besar, misalnya } \\
\text { lemari, dinding sekat dan } \\
\text { lain-lain. }\end{array}$ & 3. & $\begin{array}{l}\text { Aliran udara banyak } \\
\text { terhalang antara lain oleh } \\
\text { jemuran para penghuni } \\
\text { yang digantung di depan } \\
\text { jendela dan ventilasi } \\
\text { udara. }\end{array}$ & $\begin{array}{l}\text { 3. Udara terhalangi oleh } \\
\text { jemuran sehingga aliran } \\
\text { sedikit terganggu. }\end{array}$ \\
\hline \multicolumn{4}{|l|}{ Penerangan } \\
\hline $\begin{array}{l}\text { 1. Pada siang hari, terdapat } \\
\text { cukup banyak cahaya yang } \\
\text { masuk kedalam ruangan. }\end{array}$ & 1. & $\begin{array}{l}\text { Hanya sebagian sinar } \\
\text { matahari yang masuk ke } \\
\text { dalam ruangan. }\end{array}$ & $\begin{array}{l}\text { 1. Tidak semua unit } \\
\text { mendapatkan sinar } \\
\text { matahari karena pengaruh } \\
\text { tata letak bangunan. }\end{array}$ \\
\hline $\begin{array}{l}\text { 2. Luas jedela paling sedikit } \\
\text { mempunyai luas } 10-20 \% \\
\text { dari luas lantai. }\end{array}$ & 2. & $\begin{array}{l}\text { Luas lantai } 3 \times 6 \mathrm{~m} \text {, } \\
\text { jendela dengan ukuran } 1 \times \\
0,6 \mathrm{~m} \text { sebanyak } 3 \text { buah. }\end{array}$ & $\begin{array}{l}\text { 2. Jendela telah memenuhi } \\
\text { syarat minimum } 10-20 \% \text {. }\end{array}$ \\
\hline $\begin{array}{l}\text { 3. Penerangan buatan untuk } \\
\text { rumah per } \mathrm{m}^{2} \text { adalah } 10-20 \\
\text { Watt } / \mathrm{m}^{2}\end{array}$ & 3. & $\begin{array}{l}\text { Untuk menerangi ruangan } \\
\text { sebesar } 3 \times 6 \mathrm{~m} \text {, di tiap } \\
\text { unit rumah susun } \\
\text { digunakan lampu sebesar } \\
30 \text { Watt. }\end{array}$ & $\begin{array}{l}\text { 3. lampu yang digunakan } \\
\text { telah mencukupi standar } \\
\text { penerangan buatan. }\end{array}$ \\
\hline \multicolumn{4}{|l|}{ Pembuangan air kotor dan air hujan } \\
\hline $\begin{array}{l}\text { 1. Ukuran pipa pembawa } \\
\text { minimum } 200 \mathrm{~mm} \text {, } \\
\text { sambungan pipa harus } \\
\text { rapat air. }\end{array}$ & 1. & $\begin{array}{l}\text { Pipa penyalur dengan } \\
\text { pipa PVC ukuran } 4 \text { inchi } \\
\text { disalurkan ke tangki } \\
\text { septik. ( } 2 \text { buah) }\end{array}$ & $\begin{array}{l}\text { 1. Ukuran pipa pembawa } \\
\text { telah sesuai dengan } \\
\text { standar. }\end{array}$ \\
\hline $\begin{array}{l}\text { 2. Ukuran Tangki septik } \\
\text { bersama } \\
\text { - Panjang: } 5 \mathrm{~m} \\
\text { - Lebar : } 2,5 \mathrm{~m} \\
\text { - Kedalaman: } 1,8 \mathrm{~m}\end{array}$ & 2. & $\begin{array}{l}\text { Untuk melayani } 3 \text { blok } \\
\text { rumah susun, disediakan } \\
5 \text { buah tangki septik } \\
\text { dengan ukuran sama } \\
\text { besar yaitu } 2 \times 2 \times 5 \mathrm{~m} .\end{array}$ & $\begin{array}{l}\text { 2. Tangki septik telah } \\
\text { mencukupi kebutuhan } \\
\text { untuk melayani } 296 \text { unit } \\
\text { rumah. }\end{array}$ \\
\hline
\end{tabular}




\begin{tabular}{|c|c|c|}
\hline Standar & Keadaan sebenarnya & Analisa \\
\hline $\begin{array}{l}\text { 3. Pengurasan } \pm 2 \text { tahun } \\
\text { sekali. }\end{array}$ & $\begin{array}{l}\text { 3. Dilakukan pengurasan jika } \\
\text { sudah penuh saja, kira- } \\
\text { kira setiap } 3 \text { tahun sekali. }\end{array}$ & $\begin{array}{l}\text { 3. Sedikit berbeda dari } \\
\text { standar. }\end{array}$ \\
\hline $\begin{array}{l}\text { 4. Saluran berbentuk } 1 / 2 \\
\text { lingkaran dengan ukuran } \\
\text { minimum diameter } 20 \mathrm{~cm} \text {. }\end{array}$ & $\begin{array}{l}\text { 4. Tidak menggunakan } \\
\text { Saluran berbentuk } 1 / 2 \\
\text { lingkaran. }\end{array}$ & 4. - \\
\hline $\begin{array}{l}\text { 5. Bentuk bulat telur ukuran } \\
\text { minimum } 20 / 30 \mathrm{~cm} \text {. }\end{array}$ & $\begin{array}{l}\text { 5. Saluran terbuka dengan } \\
\text { bentuk bulat telur dengan } \\
\text { ukuran } 20 / 30 \mathrm{~cm} \text {. }\end{array}$ & $\begin{array}{l}\text { 5. saluran telah memenuhi } \\
\text { standar. }\end{array}$ \\
\hline $\begin{array}{l}\text { 6. Bahan saluran: tanah liat, } \\
\text { beton dan pasangan batu } \\
\text { bata dan bahan lain-lain. }\end{array}$ & $\begin{array}{l}\text { 6. Saluran ini terbuat dari } \\
\text { beton. }\end{array}$ & $\begin{array}{l}\text { 6. Bahan yang digunakan } \\
\text { telah memenuhi standar. }\end{array}$ \\
\hline \multicolumn{3}{|l|}{ Sampah } \\
\hline 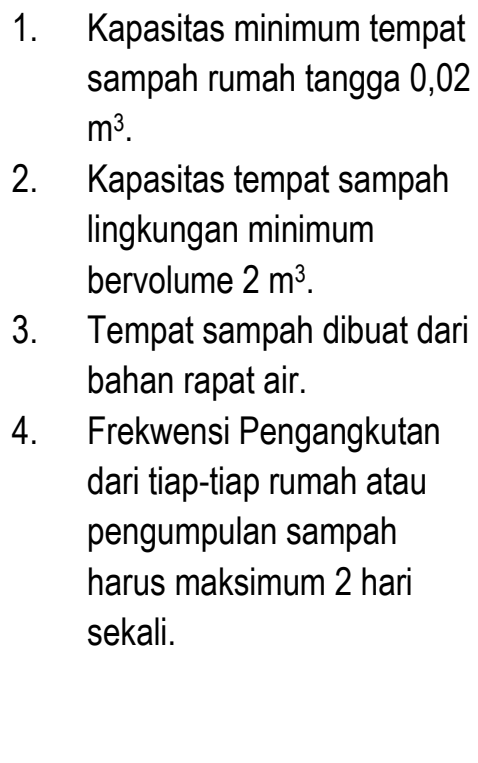 & $\begin{array}{ll}\text { 1. Untuk sampah rumah } \\
\text { tangga, berukuran } 0,4 \mathrm{x} \\
0,4 \times 0,8 \mathrm{~m} . \\
\text { 2. } \\
\text { Bak penampungan } \\
\text { sampah lingkungan } \\
\text { ukuran } 2 \times 3 \times 2 \mathrm{~m} . \\
\text { 3. } \\
\text { Tempat sampah rumah } \\
\text { tangga terbuat dari plastik } \\
\text { dan lingkungan terbuat } \\
\text { dari beton. } \\
\text { 4. Sampah rumah tangga } \\
\text { diangkut tiap hari dan } \\
\text { sampah lingkungan ini } \\
\text { dilakukan tiap seminggu } \\
\text { sekali. }\end{array}$ & $\begin{array}{l}\text { 1. Ukuran tempat sampah } \\
\text { telah sesuai dan } \\
\text { memenuhi kebutuhan. } \\
\text { 2. Ukuran tempat sampah } \\
\text { telah sesuai dan } \\
\text { memenuhi kebutuhan. } \\
\text { 3. Bahan yang digunakan } \\
\text { telah rapat air. } \\
\text { 4. Frekwensi pengangkutan } \\
\text { tidak terlalu menyimpang } \\
\text { dari standar. }\end{array}$ \\
\hline
\end{tabular}

Dari hasil penelitian dalam tabel tersebut di atas, dapat di uraikan sebagai berikut:

1) Air bersih yang digunakan sehari-hari telah memenuhi persyaratan kesehatan dan telah memenuhi kebutuhan penghuni perhari.

2) Udara dan ventilasi, dapat dikatakan memenuhi syarat karena udara tidak tercemar dan juga ventilasi yang tersedia telah dibuat sesuai ukuran yang berlaku. 
3) Penerangan, untuk penerimaan sinar matahari yang masuk ke dalam ruangan dapat di katakan cukup sedangkan untuk pemakaian lampu listrik telah memenuhi aturan yang berlaku.

4) Pembuangan air kotor dan air hujan dialirkan melalui seluran-saluran yang telah disediakan, sehingga dapat dikatakan telah memenuhi syarat dengan ketentuan yang berlaku.

5) Sampah, telah disediakan bak penampungan yang sesuai dengan peraturan baik dari jumlah maupun kapasitasnya serta sistem penanganannyapun telah memenuhi ketentuan.

\section{Diskusi Penelitian}

Dari hasil penelitian yang dilakukan terhadap sarana penyehatan lingkungan tersebut, maka diskusi penelitian yang dapat diuraikan adalah sebagai berikut:

1) Air bersih

Air bersih yang dipergunakan di lingkungan rumah susun telah memenuhi persyaratan karena bersumber dari PALIJA (PDAM). Untuk kebutuhan para penghuni, dinilai baik karena para penghuni telah terpenuhi kebutuhannya dan tidak ada keluhan dari para penghuni. Dalam pendistribusian air ke tiap-tiap unit rumah, telah memenuhi persyaratan yang ada.

Hanya saja disisi lain sering terjadi kebocoran pipa, namun ini tidak menjadi masalah yang berlarut-larut karena pihak pengelola selalu dapat mengatasinya dengan baik.

\section{2) Udara dan ventilasi}

Kualitas udara di lingkungan rumah susun tidak tercemar oleh asap kendaraan dan yang lainnya, sehingga cukup layak untuk dihirup oleh penghuninya.

Untuk pertukaran udara di dalam ruangan, tiap-tiap unit rumah susun telah menggunakan ventilasi yang sesuai dengan persyaratan yang ada. Namun keadaan ini menjadi tidak baik karena para penghuni sering menjemur pakaian di depan ventilasi udara tersebut dan ini yang menyebabkan aliran udara yang masuk ke dalam ruangan menjadi terganggu. 


\section{3) Penerangan}

Disiang hari, sinar matahari masuk ke dalam ruangan melaui jendela dan sela-sela ventilasi, namun ini tidak terjadi di setiap unit rumah susun secara keseluruhan. Ini terjadi karena letak bangunan yang tidak sejajar dengan arah sinar matahari.

Untuk penerangan buatan, dapat dikatakan cukup karena telah memenuhi syarat-syarat penerangan dengan 60 Watt untuk menerangi ruangan dengan luas $3 \times 6 \mathrm{~m}$.

\section{4) Saluran Pembuangan}

a. Pembuangan Air Kotor

Penyaluran pembuangan air kotor dari tiap-tiap unit rumah susun dialirkan ke tangki septik. Secara keseluruhan proses pembuangan air kotor ini, telah dibuat sesuai dengan ketentuanketentuan yang berlaku.

Namun demikian masih terdapt masalah yang sering timbul antara lain adalah kebocoran pada pipa penghantar dan juga saluran yang terhambat. Mengenai kebocoran pipa, pihak pengelola hanya mau bertanggungjawab apabila kebocoran tersebut terjadi di luar unit rumah sedangkan bila terjadi di dalam unit rumah, maka kebocoran pipa tersebut menjadi tanggungjawab tiap-tiap penghuni tersebut. Apabila terjadi mampet atau saluran terhambat, maka pihak pengelola bertanggungjawab langsung dan segera memperbaikinya.

\section{b. Pembuangan Air Hujan}

Untuk pembuangan air hujan, di kawasan rumah susun ini dialirkan kedalam sumur resapan dan ada juga yang langsung dialirkan kesaluran kota. Saluran pembuangan air hujan yang digunakan telah dibuat sesuai dengan peraturan yang ada.

Biasanya masalah yang sering timbul hanya salurannya yang tidak mampu menampung debit air yang tinggi sehingga meluap keatas dan menyebabkan genangan air.

\section{5) Sampah}

Sistem pembungan sampah yang dilakukan pihak pengelola rumah susun secara keseluruhan sudah baik. Dari segi pengadaan sarana, perawatan dan pemeliharaan juga sudah memenuhi persyaratan yang ada. 
Untuk masalah sampah di rumah susun ini, jarang terjadi keluhan dari penghuninya. Biasanya keluhan terjadi bila ada penumpukan sampah yang menyebabkan bau yang menyengat, ini terjadi bila pengangkutan sampat terlambat.

\section{E. Kelemahan Hasil Penelitian}

Sebagai peneliti merasa sangat banyak kelemahan-kelemahan di dalam melaksanakan penelitian ini, kelemahan-kelamahan tersebut antara lain:

1) Terbatasnya waktu pelaksanaan penelitian, sehingga survei dan observasi yang dilakukan terasa belum maksimal.

2) Kekurangan dalam menyusun butir-butir pertanyaan yang disebabkan keterbatasan dalam penggunaan Bahasa Indonesia yang baik, sehingga hasil yang didapat dalam survey dan observasi masih sangat terbatas.

3) Kurangnya informasi yang diberikan oleh pihak pengelola menyebabkan informasi yang didapat hanya pada hal-hal yang baik saja.

\section{KESIMPULAN}

Berdasarkan hasil penelitian diambil kesimpulan sebagai berikut:

1. Sarana penyehatan lingkungan dikawasan rumah susun Pejompongan Jakarta Pusat yang meliputi: air bersih, udara dan ventilasi, penerangan, pembuangan air kotor dan air hujan serta sampah telah memenuhi syarat-syarat kesehatan dan dapat dikatakan baik.

2. Kekurangan yang terjadi pada sarana penyehatan lingkungan di kawasan rumah susun, biasanya terjadi karena kebiasaan buruk yang dilakukan oleh penghuni itu sendiri.

3. Sarana penyehatan lingkungan rumah susun telah dapat dimanfaatkan oleh para penghuni dan pihak pengelola telah melakukan kewajibannya dengan baik.

\section{DAFTAR PUSTAKA}

Eko Budihardjo, Sejumlah Masalah Pemukiman Kota (Bandung: Alumni, 1984) 